\title{
THE EFFECT OF ENTREPRENEURSHIP EDUCATION ON MARKETING DEVELOPMENT IN CULINARY MICRO SMALL MEDIUM ENTREPRISES (MSMES) AT BANDUNG DISTRICT
}

Muhammad Ridha Rachman ${ }^{1}$, Maria Sugiat ${ }^{2}$

${ }^{1,2}$ Universitas Telkom

Email: mridharachman@student.telkomuniversity.ac.id

\begin{abstract}
In Bandung District, many Micro, Small and Medium Enterprises (MSMEs) are not familiar with entrepreneurship education due to limited access. Meanwhile, the potential of Micro, Small and Medium Enterprises (MSMEs) is very large, especially in the culinary field. In fact, Micro, Small, and Medium Enterprises (MSMEs) can contribute as much as 57.8\% of Indonesia's Gross Domestic Product (GDP) income. The purpose of this study was to determine how the effect of entrepreneurship education on the development of marketing in the culinary field in Micro, Small and Medium Enterprises (MSMEs) Bandung District. Collecting data using quantitative methods through a survey using an online questionnaire instrument to 50 respondents of culinary Micro, Small and Medium Enterprises (MSMEs) in Bandung District. The results showed that there was a positive and significant influence of entrepreneurship education on the development of the culinary Micro, Small and Medium Enterprises (MSMEs) market in Bandung District. The facts prove that all the respondents studied relied on self-taught methods to learn business, without being given special education about entrepreneurship. Therefore, this phenomenon results in the difficulty of marketing development carried out by culinary Micro, Small and Medium Enterprises (MSMEs) in Bandung District due to the absence of entrepreneurial education obtained by culinary Micro, Small and Medium Enterprises (MSMEs) in Bandung District.
\end{abstract}

Keywords: Bandung district, entrepreneurship education, marketing development, MSMEs

\section{INTRODUCTION}

The phenomenon of the failure of a business can be a common phenomenon that is often found in one's business activities, especially for Micro, Small and Medium Enterprises (MSMEs). In fact, according to the facts stated by Suryana (2001), the age of 5 years is the age of many Micro, Small and Medium Enterprises (MSMEs) experiencing failure or what is commonly called the failure rate. The failure rate for small businesses in Indonesia can reach $78 \%$.

The obstacle that often arises and can lead to failure from the entrepreneurial activities of Micro, Small and Medium Enterprises (MSMEs) is the difficulty of developing the existing market. As supported by the opinion of Gunatin (2017) which states that there are several general things that often become obstacles for Micro, Small and Medium Enterprises (MSMEs) in Indonesia to 
develop, namely weak marketing strategies (marketing), weak creativity and innovation, Human Resources (HR) who are less competent, business capital, and weak ability to read opportunities. The role of entrepreneurship education to be able to minimize this failure is very important. With the existence of education, the hope that arises is that more and more Micro, Small and Medium Enterprises (MSMEs) actors will be more educated on how to run a good and correct business, so that failure can be minimized.

Especially in entrepreneurship education, Indonesian citizens have the right to get it. The Indonesian government has arranged in such a way that its citizens can have the same right to receive entrepreneurship education. So, this has been written in Article 19 letter c of Law No. 20 of 2008 concerning Micro, Small and Medium Enterprises (MSMEs) which reads "forming and developing educational institutions, training, counselling on business motivation and creativity, and the creation of new entrepreneurs."

Behind the obstacles that occur, the potential of Micro, Small and Medium Enterprises (MSMEs) in Indonesia is very important. According to data reported by the Ministry of Cooperatives, Small and Medium Enterprises (2018), Indonesian Micro, Small and Medium Enterprises (SMEs) also contributed IDR 8,573.9 trillion to Indonesia's Gross Domestic Product (GDP). Meanwhile, the Gross Domestic Product (GDP) in Indonesia in the same year was IDR 14,838.3 trillion. So, this means that Micro, Small and Medium Enterprises (MSMEs) in Indonesia contribute up to $57.8 \%$ of the Gross Domestic Product (GDP) in Indonesia.

Therefore, based on the data and observations above, the author intends to conduct a study entitled "The Effect of Entrepreneurship Education on Marketing Development in Micro, Small and Medium Enterprises (MSMEs) Culinary Bandung District)". The author will research to find out how the influence of entrepreneurship education will have an impact on marketing development of culinary Micro, Small and Medium Enterprises (MSMEs) in Bandung District. It is hoped that this research can reflect the actual conditions of existing phenomena that can produce valuable and useful findings for Micro, Small and Medium Enterprises (MSMEs) in Indonesia.

\section{METHOD}

This research is a descriptive research, which is research that aims to prove the existence of empirical truth from the research hypothesis proposed regarding the relationship between two or more research variables (Aritonang R., 2007). This study uses an associative quantitative method by distributing questionnaires to the research objects. 
The data used are primary data, namely data obtained directly by the researcher which is related to the test variables based on the objectives of the study. The instrument used in this research is a questionnaire that can be administered as well as from the number of research objects (Aritonang R., 2007).

The variables tested were the variables entrepreneurship education and marketing development. Where the indicators of entrepreneurship education variables are educational methods, educational materials, teaching objectives, and growing business opportunities (Bukirom, 2014). While the indicators measured in the marketing development variable are innovation orientation, bottom-up approach, interactive marketing methods, Word of Mouth (WOM), and direct selling (Stokes, 2012). In this study, the researcher predicted how the relationship between the two variables used multiple linear regression analysis techniques.

But before that, the researcher distributed questionnaires to 35 respondents to find out the size of the variable under study whether it was valid or not by using the validity test. The following are the results of the validity test:

Table 1. Validity Test

\begin{tabular}{|c|c|c|c|c|}
\hline Variable & Measure & R count & $\mathrm{R}$ list $5 \%$ & Criteria \\
\hline \multirow[t]{10}{*}{ Entrepreneur Education } & $\begin{array}{l}\text { 1. Understanding of } \\
\text { educational } \\
\text { methods }\end{array}$ & 0,765 & \multirow{10}{*}{0,334} & Valid \\
\hline & $\begin{array}{l}\text { 2. Innovative } \\
\text { educational } \\
\text { methods }\end{array}$ & 0,809 & & Valid \\
\hline & $\begin{array}{l}\text { 3. Creativity } \\
\text { educational } \\
\text { methods }\end{array}$ & 0,795 & & Valid \\
\hline & $\begin{array}{l}\text { 4. Can be a solution } \\
\text { to problems }\end{array}$ & 0,634 & & Valid \\
\hline & 5. Latest (times) & 0,815 & & Valid \\
\hline & 6. Can add insight & 0,798 & & Valid \\
\hline & 7. Can be practiced & 0,808 & & Valid \\
\hline & $\begin{array}{l}\text { 8. Creating new } \\
\text { markets }\end{array}$ & 0,723 & & Valid \\
\hline & $\begin{array}{l}\text { 9. Creating new } \\
\text { products }\end{array}$ & 0,748 & & Valid \\
\hline & $\begin{array}{l}\text { 10. Creating new } \\
\text { business networking } \\
\text { (network) }\end{array}$ & 0,649 & & Valid \\
\hline
\end{tabular}




\begin{tabular}{|c|c|c|c|}
\hline Development Marketing & $\begin{array}{l}\text { 1. Innovation in } \\
\text { marketing methods }\end{array}$ & 0,640 & \\
\hline & $\begin{array}{l}\text { 2. Product } \\
\text { innovation }\end{array}$ & 0,718 & \\
\hline & $\begin{array}{l}\text { 3. Development of a } \\
\text { niche market }\end{array}$ & 0,773 & \\
\hline & $\begin{array}{l}\text { 4. Content } \\
\text { marketing methods }\end{array}$ & 0,673 & 0,334 \\
\hline & $\begin{array}{l}\text { 5. Creative } \\
\text { marketing methods }\end{array}$ & 0,593 & \\
\hline & 6. Online marketing & 0,745 & \\
\hline & $\begin{array}{l}\text { 7. The entrepreneur } \\
\text { community }\end{array}$ & 0,669 & \\
\hline & $\begin{array}{l}\text { 8. Business } \\
\text { cooperation }\end{array}$ & 0,711 & \\
\hline
\end{tabular}

The population used in this study were culinary Micro, Small and Medium Enterprises (MSMEs) in Bandung District. The sampling technique in this study uses purposive sampling technique, the sampling technique using selected populations to be sampled based on the research objectives and it is known how the characteristics of the research sample (Aritonang R., 2007). The sample in this research were 50 culinary business activists in Bandung District.

In this study, data processing for testing and analysis using the IBM SPSS 25 software.

\section{FINDINGS AND DISCUSSION}

Various types of characters from 50 culinary Micro, Small and Medium Enterprises (MSMEs) actors of Bandung District who were used as respondents in this study provided complementary data from the variables studied, following the various types and types of these characters can be seen in table 2 below.

Table 2. Types of Characteristics of culinary Micro, Small and Medium Enterprises (MSMEs) in Bandung District

\begin{tabular}{lcc}
\hline Types of Characteristic & Information & Total \\
\hline Business Product & Cakes & 18 \\
& Snacks & 14 \\
& Rice (entree) & 10 \\
& Drinks & 8
\end{tabular}




\begin{tabular}{lcc} 
Length of Business & 1-5 years & 25 \\
& 5-10 years & 17 \\
& 10-15 years & 8 \\
& & \\
Business Founder & Individual & 28 \\
& Family & 16 \\
& Group & 6 \\
Business Turnover (per & & \\
month) & $<$ Rp1.000.000 & 18 \\
& Rp1.000.000- & 23 \\
& Rp5.000.000 & \\
& Rp5.000.000- & 9 \\
& Rp10.000.000 & \\
\hline
\end{tabular}

The data generated through a questionnaire instrument filled in by 50 respondents of culinary Micro, Small and Medium Enterprises (MSMEs) in Bandung District, with the majority of the business being under 5 years, resulted in data that these Micro, Small and Medium Enterprises (MSMEs) entrepreneurs gained access to entrepreneurship education through self-learning, although sometimes getting access to entrepreneurship education through training obtained from formal or informal institutions. With a business that is established individually or in a family, culinary Micro, Small and Medium Enterprises (MSMEs) in Bandung District admitted that the product marketing process that is carried out is relying heavily on the Word of Mouth (WoM) way, compared to the process of developing online marketing (e-commerce, online delivery, social media). With these business process activities, the majority of Micro, Small and Medium Enterprises (MSMEs) get a monthly turnover of less than IDR 1,000,000. In addition, the main problem that exists in culinary Micro, Small and Medium Enterprises (MSMEs) in Bandung District is not precisely because of the difficulty of getting access to entrepreneurship education, but culinary Micro, Small and Medium Enterprises (MSMEs) in Bandung District admit that the main problem they feel is in the process of activity. the business he is doing is the difficulty of carrying out market development. This is due to the existence of a variable entrepreneurial education material that is not in accordance with the needs of culinary Micro, Small and Medium Enterprises (MSMEs) in Bandung District. Therefore, culinary Micro, Small and Medium Enterprises (MSMEs) actors in Bandung District really hope for a solution of action from existing stakeholders. 
The results of multiple linear regression analysis to determine how the influence of the entrepreneur education variable $(\mathrm{X})$ on $(\mathrm{Y})$ is as follows:

Table 3. The Results of Multiple Linear Regression Analysis

\section{Coefficients}

\begin{tabular}{|c|l|r|r|r|r|r|}
\hline \multicolumn{2}{|c|}{ Model } & \multicolumn{2}{|c|}{$\begin{array}{c}\text { Unstandardized } \\
\text { Coefficients }\end{array}$} & $\begin{array}{c}\text { Standardized } \\
\text { Coefficients }\end{array}$ & \multirow{2}{*}{ t } & \multirow{2}{*}{ Sig. } \\
\cline { 3 - 7 } \multicolumn{2}{|c|}{} & B & $\begin{array}{c}\text { Std. } \\
\text { Error }\end{array}$ & Beta & & \\
\hline 1 & (Constant) & 10.820 & 3.159 & & 3.425 & 0.002 \\
\hline \multirow{2}{*}{$\begin{array}{l}\text { Entrepreneur } \\
\text { Education } \\
\text { (X) }\end{array}$} & 0.477 & 0.092 & 0.668 & 5.155 & 0.000 \\
\hline
\end{tabular}

a. Dependent Variable: Development Marketing (Y)

Based on data analysis using SPSS version 26 software, the results of the regression equation are as follows:

$Y=10.820+0,477_{X}+e$

The regression equation above shows the relationship between the independent variable and the dependent variable partially, from this equation it can be concluded that:

1. The constant value is 10,820 , meaning that if there is no change in the entrepreneur education variable ( $\mathrm{X}$ value is 0 ), then the development marketing at MSMEs in Bandung District is 10,820 units.

2. The regression coefficient value for entrepreneur education $(X)$ is 0.477 , meaning that if the entrepreneur education variable $(\mathrm{X})$ increases by $1 \%$, then development marketing at MSMEs in Bandung District increases by 0.477. This shows that the entrepreneur education variable that is carried out contributes positively to marketing development, so that the more complex entrepreneur education carried out by Bandung District MSMEs, the higher the level of development marketing that Bandung District MSMEs do.

This result is in line with how previous research conducted by (Yud Buana, 2017) examined the positive influence of entrepreneurship education on entrepreneurial intention towards the object of research being carried out, namely university students.

\section{CONCLUSIONS}


Based on the results of these tests, it can be concluded that there is an the effect of entrepreneurship education on market development in the culinary Micro Small and Medium Enterprises (MSMEs) of Bandung District. From the existence of an entrepreneurial education process that is not optimal, it will have an impact on the difficulty of business actors to develop marketing from every business activity.

Based on existing research objectives, namely to find out how the influence of entrepreneurship education on marketing development at culinary MSMEs in Bandung District, it turns out that entrepreneurship education has a positive influence on marketing development. So, the higher the entrepreneurship education is carried out, the higher the results and marketing development activities will be.

Based on the resulting research, it can be summarized that the variables of entrepreneurship education with indicators of educational methods, educational materials, teaching objectives, and growing business opportunities (Bukirom, 2014) have a significant influence on marketing development variables with indicators measured in the marketing development variable are innovation orientation, bottom-up approach, interactive marketing methods, Word of Mouth (WOM), and direct selling (Stokes, 2012).

In addition, suggestions that can be given from the author for further research to deepen the knowledge related to this research are that researchers can use a wider sample, so that the results of the research can be easily generalized into a wider scope. As well as researchers can increase the number of variables in their research, such as networking expansion, entrepreneurial interest, entrepreneurial behavior, and so on. That way, this research can complement and deepen the results of this research.

From this information, it is imperative that culinary MSMEs in Bandung District can immediately improve entrepreneurship education that is carried out, both formal and informal. With an increase in entrepreneurship education, the higher the marketing development that will be obtained. And of course this will have a positive impact on the progress of culinary MSMEs in Bandung District.

\section{REFERENCES}

Purnami, I. G. (2016). Pengaruh Pendidikan Kewirausahaan, Self Efficacy Dan Locus Of Control Pada Niat Berwirausaha. E-Jurnal Manajemen Unud, Vol. 5, No. 22, 1164.

Jayani, D. H. (2020, May 20). Berapa Sumbangan UMKM Terhadap Perekonomian Indonesia? Retrieved from databoks.katadata.co.id: https://databoks.katadata.co.id/datapublish/2020/05/20/berapa-sumbangan-umkmterhadap-perekonomian-indonesia\# 
Kusumandari, R. B. (2013). Model Pendidikan Kewirausahaan Dalam Mengembangkan Jiwa Wirausaha Siswa Smk Unggulan. Jejak (Journal of Economics and Policy) , 67.

Muhammad Yusri Ali dan Dr. David Sukardi Kodrat, M. C. (2017). Faktor-Faktor Penyebab Kegagalan Bisnis Pada. Performa: Jurnal Manajemen dan Start-Up Bisnis, Volume 2, No. $1,125$.

Pamuji, M. (2018). Entrepreneurial Marketing: Mengintegrasikan Pemasaran dan Kewirausahaan Dalam Upaya Meningkatkan Kinerja. Jurnal Ekonomi Global Masa Kini Mandiri, Volume 9, No. 1, 10-11.

Aditya, R. (2019). Pengaruh Pendidikan Kewirausahaan Terhadap Niat Berwirausaha Yang Dimediasi Efikasi Diri Mahasiswa Manajemen. Jurnal Manajerial dan Kewirausahaan, Volume 1, No. 4, 645-655.

Endah Wahyuningsih (2017). Membangun Jejaring Kewirausahaan Melalui Keunggulan Usaha Konveksi Untuk Meningkatkan Kinerja Pemasaran. Teknobuga, Volume 4, No. 1, 80.

Tohani, E. (2015). Dampak Pendidikan Kewirausahaan Masyarakat (PKuM). Jurnal Ilmiah VISI PPTK PAUDNI, Volume 10, No. 1, 44.

Buana, Y. ( 2017). The Effect of Entrepreneurship Education on Entrepreneurial Intention of University Students by Adopting Linan Model. Binus Business Review. 